\title{
Association of benthic macrofauna with habitat types and quality in the New York Bight
}

\author{
Sukwoo Chang, Frank W. Steimle, Robert N. Reid, Steven A. Fromm, \\ Vincent S. Zdanowicz, Robert A. Pikanowski
}

U.S. Department of Commerce, National Oceanic and Atmospheric Administration, National Marine Fisheries Service, Northeast Fisheries Center, Sandy Hook Laboratory, Highlands, New Jersey 07732, USA

\begin{abstract}
Previous qualitative and limited quantitative analyses of benthic data from the New York Bight, USA, have suggested associations among macrofauna and sediment characteristics, including levels of chemical contamination. Benthic data from 3 summers (1980 to 1982) of sampling were used to examine more thoroughly these relationships. Factor and canonical analyses confirmed that a limited group of macrofaunal taxa (Ceriantheopsis americanus, Nephtys incisa, Capitella spp., Nucula proxima and Ampelisca agassizi), historically considered indicators of habitat quality, were indeed valid indicators. Ordination analyses provided greater detail about the association of, and between, sediment variables and the 80 most frequently occurring species. The results allowed a characterization of the New York Bight benthic habitat, encompassing the range from an undisturbed habitat to the lowest quality habitat. One species group was consistently associated with minimally contaminated sediments and appears to represent a basic natural benthic macrofaunal assemblage for the Bight. This group included taxa such as the sand dollar Echinarachnius parma and several species of amphipods (e.g. Byblis serrata, Corophium crassicorne and Ampelisca agassizi) as well as some polychaetes (e.g. Goniadella gracilis and Exogone hebes). Species that were the most common in the contaminated areas of the Bight were mainly polychaetes (e.g. Tharyx acutus, Nephtys incisa, Pherusa affinis and Capitella spp.) as well as the Nemertinea (Cerebratulus lacteus), an anemone (Ceriantheopsis americanus), a phoronid (Phoronis architecta) and the nut clam Nucula proxima.
\end{abstract}

\section{INTRODUCTION}

Studies of benthic macrofauna abundance and distribution in the New York Bight, USA, have been used for decades to assess effects of waste disposal (Rowe 1971, Pearce et al. 1976, Reid et al. 1982, Steimle et al. 1982, Caracciolo \& Steimle 1983, Steimle 1985, 1990. Reid et al. unpubl.). Associations between macrofauna and habitat defined in these studies were usually based on congruence of sediment types or contamination levels with distribution patterns of certain benthic macrofaunal communities or taxon abundance. Quantitative statistical examinations of these relations in the New York Bight have been limited, however. For example, Saila et al. (1976) investigated optimum sampling strategies to assess effects of waste disposal, using benthic data collected in the early 1970's. Walker et al. (1979), using a subset of the same data, suggested that post-collection stratification, based on environmental gradients, might be a suitable procedure for controlling variability when assessing waste disposal effects. Boesch et al. (unpubl.) used multivariate analysis of the same data to attempt to relate contamination and other environmental factors to observed biological patterns. Reid et al. (1982) presented a correlation analysis of data from the 1980 survey considered here, and Reid et al. (1991) conducted cluster analysis of multi-year (1980 to 1985) data for the same stations.

In this paper we used several parametric and nonparametric statistical procedures to analyze benthic macrofauna and sediment data collected in the New York Bight during the summers of 1980 to 1982. The purpose of this analysis was 2-fold: (1) to examine previously suggested associations between a small group of benthic macrofaunal 'indicator' taxa and sediment variables, such as grain size, organic carbon and trace metal content; and (2) to use a broader proportion of the benthic community to further define associations between assumed 'critical' sediment characteristics and patterns of other benthic macrofaunal species distributions. 


\section{METHODS}

Benthic macrofauna and sediment data used in our analyses were from samples collected at 45 to 49 fixed stations encompassing a range of sediment types and contamination levels in the New York Bight (Fig. 1).

Sampling procedures and station locations, depths and sediment characteristics were detailed in Reid et al. $(1982,1991)$. Briefly, one or more $0.1 \mathrm{~m}^{2}$ SmithMcIntyre grab samples were taken at each station. From each sample, small core subsamples were removed for sediment analysis. The remainder of the sample was washed through a $0.5 \mathrm{~mm}$ mesh sieve for macrofauna. The number of grab samples collected was based on a variable monitoring strategy (Reid et al. 1991). In late July-early August of 1980, 45 stations were sampled (Stns 1 to 44 \& P13, Fig. 1). This sampling was repeated in August 1981 and September 1982 with 4 stations added (Stns 63, 64, 65 \& 158, Fig. 1). Seven of the stations $(4,6,7,15,26,31 \&$ P13) were sampled as part of the NOAA's Northeast Monitoring Program with 5 replicate grab samples routinely collected for sediment and benthic macrofauna analysis. Usually single samples were taken at remaining stations in 1980 and 1981, with 2 samples per station in 1982. For our analyses, data from replicate samples were averaged.

Sediment core subsamples were analyzed for: mean sediment grain size (MN); percent of finer grain size
(GS), i.e. silts and clays; concentrations of 3 trace metals, chromium $(\mathrm{Cr})$, lead $(\mathrm{Pb})$ and zinc $(\mathrm{Zn})$; percent total organic carbon (TOC); and total Kjeldahl nitrogen (TKN). The chemicals measured are not necessarily contaminants, but at elevated levels are considered an indication of anthropogenic contamination.

Earlier studies (Walker et al. 1979, Reid et al. 1982, Boesch et al. unpubl.) suggested that densities of some benthic taxa were strongly associated with certain sediment variables; however, this was based on limited statistical evaluation. Species reported to be useful indicators of different habitat types and conditions included: the tube-dwelling anemone Ceriantheopsis americanus, the polychaetes Nephtys incisa and Capitella spp., the nut clam Nucula proxima and the tube-dwelling amphipod Ampelisca agassizi. These earlier studies, and Steimle (1985), also suggested that biomass and numbers of species of amphipods, crustaceans and the entire benthic macrofaunal community appear to be sensitive taxa measures. Capitella spp. are widely recognized as indicators of organic pollution (Halcrow et al. 1973, Pearson \& Rosenberg 1978) or other major habitat disturbances (Eagle \& Rees 1973, Pearson \& Rosenberg 1978). The Capitella spp. population discussed here may not be a single species, but a complex of morphometrically similar species (Grassle \& Grassle 1976). Elevated values of TOC in the sediment of the inner New York Bight are thought to enhance the abundance of some species such as

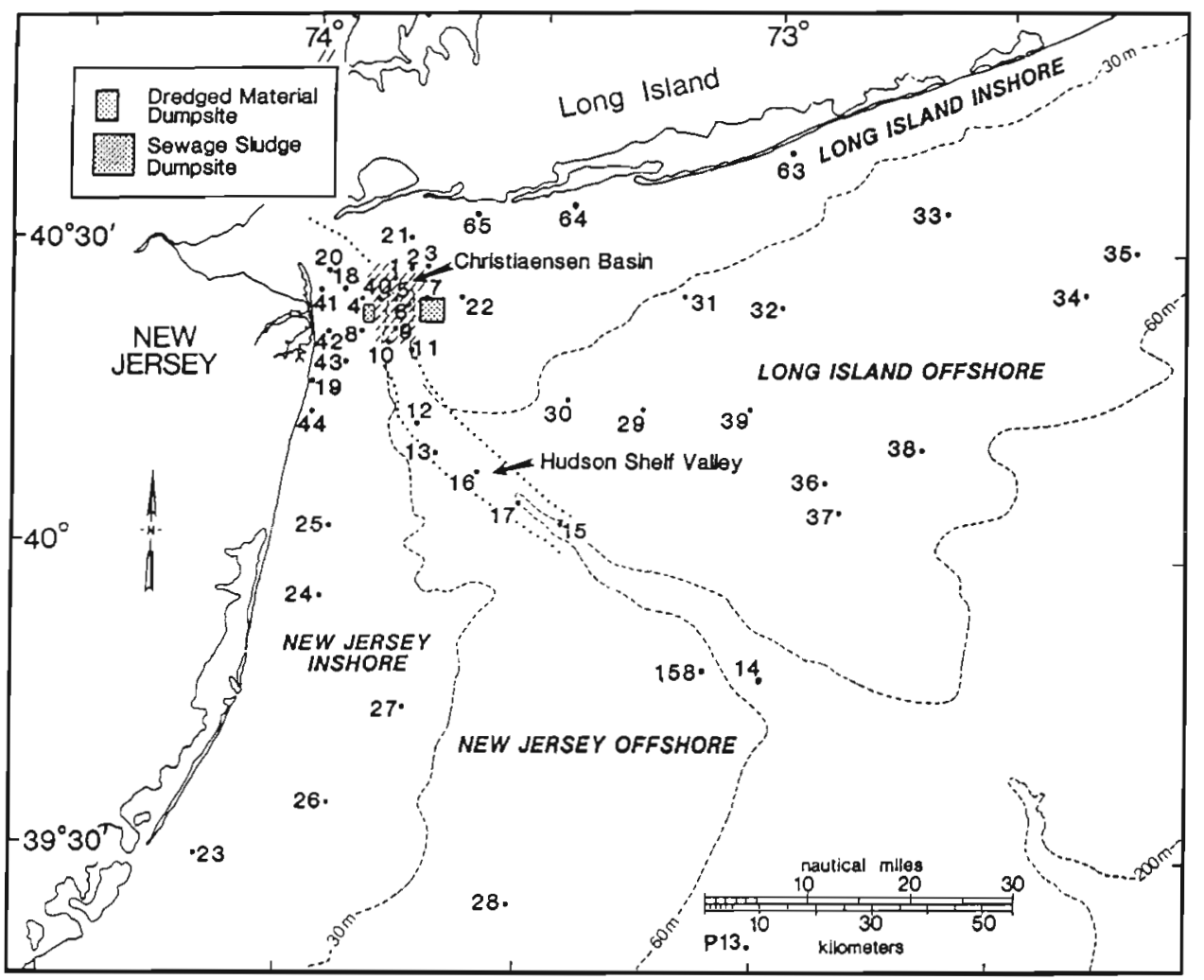

Fig. 1. Station locations in the New York Bight. Five replicate grab samples were taken each summer (1980 through 1982) at 'Northeast Monitoring Program' stations $(4,6,7$, $15,26,31 \&$ P 13); at remaining stations, 1 to 2 grab samples were taken (Reid et al. 1991) 
C. americanus, $N$. incisa and $N$. proxima (Pearson \& Rosenberg 1978, Steimle 1985). On the other hand, the amphipod genus Ampelisca (Lee et al. 1977, Sanders et al. 1980), amphipods and crustaceans in general (Pearson \& Rosenberg 1978), and total number of species in a community (Green \& Vascotto 1978) are reported to be negatively affected by even low levels of habitat contamination.

The influence of sediment characteristics on the distribution of benthic organisms is well established (Johnson 1971, Rhoads 1974, Sanders et al. 1980). Large within-station variances in New York Bight benthic data result, in part, from the high local spatial variability of sediment types (Stubblefield et al. 1974) and the patchy or aggregative distribution of some benthic species. To reduce the standard error of the mean (by increasing sample size) we pooled all samples taken over all years per station. To test the validity of this pooling, a non-parametric, multivariate rank sum test was used, with chi-square as the test statistic (Puri \& Sen 1971). This test shows whether several independent samples have been drawn from the same population. High chi-square values imply non-homogeneity between the different annual survey data. Only 7 of the 23 variables examined showed significant $(\alpha=0.05)$ interannual differences (Table 1). We considered this insufficient to prevent using the pooled data for further analyses as

Table 1. Results of the rank sum test (Puri \& Sen 1971) for determining the validity of combining 3 years (1980 to 1982) of New York Bight sediment and benthic macrofaunal data

\begin{tabular}{|lr|}
\hline Variable & Test statistic \\
\hline Mean sediment grain size (MN) & 1.946 \\
Total organic carbon (TOC) & 0.984 \\
Total Kjeldahl nitrogen (TKN) & $13.621^{\circ}$ \\
Chromium concentration (Cr) & $6.929^{\circ}$ \\
Lead concentration (Pb) & 1.527 \\
Zinc concentration (Zn) & 1.181 \\
Ceriantheopsis americanus (density) & $13.561^{\circ}$ \\
C. americanus (biomass) & $8.048^{\circ}$ \\
Nephtys incisa (density) & 2.321 \\
N. incisa (biomass) & 2.289 \\
Capitella spp. (density) & $6.121^{\circ}$ \\
Capitella spp. (biomass) & 5.712 \\
Nucula proxima (density) & 3.416 \\
N. proxima (biomass) & 1.866 \\
Ampelisca agassizi (density) & 1.642 \\
A. agassizi (biomass) & 1.748 \\
All amphipods (biomass) & 2.404 \\
All amphipods (no.of species) & 3.535 \\
All crustaceans (biomass) & 0.239 \\
All crustaceans (no. of species) & $6.043^{\circ}$ \\
All species (biomass) & 3.840 \\
All species (no. of species) & $10.080^{\circ}$ \\
& \\
- Significant at 95\% level & \\
\hline
\end{tabular}

the gain in precision should outweigh possible misclassifications caused by averaging.

To reduce variability further, stations were grouped into strata representing various habitat types. These strata were categorized according to levels of 3 highly correlated sediment variables: mean grain size, total organic carbon and chromium. This is similar to the post-collection stratification approach suggested by Walker et al. (1979). The range of values of each categorizing variable was then subdivided: (1) four levels (coarser, $C$; medium, $M$; fine, $F$; and very fine, $V$ ) of mean grain size (MN), a measure of benthic boundary layer hydrodynamics, depositional regime and habitat suitability usually considered a strong determinant of benthic assemblages; (2) two levels (high, $\mathrm{H}$, and low, L) of TOC, a measure of nutrient enrichment; and (3) two levels (high, $\mathrm{H}$, and low, L) of $\mathrm{Cr}$ concentration, a representative measure of toxic chemical contamination. The thresholds used to partition the range of sediment variable levels were based on results of previous studies, for example, Walker et al. (1979), Long \& Morgan (1990), Boesch et al. (unpubl.) and more recent work (Packer et al. unpubl.). Thus, sixteen $(4 \times 2 \times 2)$ post-collection strata were defined from the sediment data (Table 2). Characteristics of each stratum are coded by stringing the sediment variable level codes for MN, TOC, and $\mathrm{Cr}$ respectively. For example, Stratum 15 is represented by VLH, meaning the stratum is characterized by very fine grain size, low total organic carbon, and high $\mathrm{Cr}$ concentration (see Table 2). The survey data occupied only 10 of the 16 possible strata. Because of autocorrelation between the stratifying variables, the unoccupied strata may either not occur in the Bight ( $\mathrm{CHH}$, for example), or be present in isolated pockets and not sampled. Stations were assigned to strata according to characterizing variables (Table 3).

For each sediment or biological variable, Box \& Cox (1964) tests were used to select the best transformation to maximize log-likelihood function; the square-root transformation was the best fit for MN and the logarithmic transformation for other sediment and fauna variables. Normality of the transformed data was assessed with the Kolmogorov-Smirnov test for goodness of fit (Siegel 1956) and found to be acceptable. For the putative indicator species assemblages, an analysis of variance (ANOVA) and Tukey's multiple range test (Steele \& Torrie 1960) were used to assess significant differences between strata. A correlation matrix was generated between all sediment variables and all indicator taxa. This matrix became the basis for the factor and canonical correlation analyses (Cooley \& Lohnes 1971).

Double ordination was used as a classification procedure to explicitly define strata and species groupings. 
Table 2. Benthic habitat stratum (Str.) in the New York Bight Apex based on 4 levels of mean sediment grain sizes and 2 levels each of total organic carbon (TOC, \%) and chromium concentration ( $\mathrm{Cr}, \mathrm{ppm}$ dry wt)

\begin{tabular}{|c|c|c|c|c|}
\hline Str. & $\begin{array}{l}\text { Str. } \\
\text { code }\end{array}$ & $\begin{array}{l}\text { Mean grain } \\
\text { size }(\phi)\end{array}$ & TOC & $\mathrm{Cr}$ \\
\hline $1^{\mathrm{d}}$ & CLL & $M N \leq 0.0$ & $\leq 5.0$ & $\leq 30.0$ \\
\hline 2 & $\mathrm{CHL}$ & $\mathrm{MN} \leq 0.0$ & $>5.0$ & $\leq 30.0$ \\
\hline $3^{d}$ & MLL & $0.0<\mathrm{MN} \leq 2.0$ & $\leq 5.0$ & $\leq 30.0$ \\
\hline 4 & MHL & $0.0<\mathrm{MN} \leq 2.0$ & $>5.0$ & $\leq 30.0$ \\
\hline $5^{i}$ & FLL & $2.0<\mathrm{MN} \leq 5.0$ & $\leq 5.0$ & $\leq 30.0$ \\
\hline $6^{\circ}$ & FHL & $2.0<\mathrm{MN} \leq 5.0$ & $>5.0$ & $\leq 30.0$ \\
\hline 7 & VLL & $\mathrm{MN}>5.0$ & $\leq 5.0$ & $\leq 30.0$ \\
\hline $8^{\mathrm{a}}$ & VHL & $\mathrm{MN}>5.0$ & $>5.0$ & $\leq 30.0$ \\
\hline 9 & CLH & $\mathrm{MN} \leq 0.0$ & $\leq 5.0$ & $>30.0$ \\
\hline 10 & $\mathrm{CHH}$ & $M N \leq 0.0$ & $>5.0$ & $>30.0$ \\
\hline $11^{\mathrm{a}}$ & MLH & $0.0<\mathrm{MN} \leq 2.0$ & $\leq 5.0$ & $>30.0$ \\
\hline $12^{d}$ & $\mathrm{MHH}$ & $0.0<\mathrm{MN} \leq 2.0$ & $>5.0$ & $>30.0$ \\
\hline 13 & FLH & $2.0<\mathrm{MN} \leq 5.0$ & $\leq 5.0$ & $>30.0$ \\
\hline $14^{\mathrm{a}}$ & $\mathrm{FHH}$ & $2.0<\mathrm{MN} \leq 5.0$ & $>5.0$ & $>30.0$ \\
\hline $15^{d}$ & VLH & $\mathrm{MN}>5.0$ & $\leq 5.0$ & $>30.0$ \\
\hline $16^{\Delta}$ & VHH & $\mathrm{MN}>5.0$ & $>5.0$ & $>30.00$ \\
\hline \multicolumn{5}{|c|}{${ }^{d}$ Strata containing data } \\
\hline \multicolumn{5}{|c|}{${ }^{b}$ Codes for sediment characteristics: } \\
\hline \multirow{4}{*}{\multicolumn{2}{|c|}{4 levels of $M N$}} & $C=$ Coarse & \multirow{4}{*}{\multicolumn{2}{|c|}{$\begin{array}{r}\mathrm{MN} \leq 0.0 \phi \\
0.0<\mathrm{MN} \leq 2.0 \phi \\
2.0<\mathrm{MN} \leq 5.0 \phi \\
\mathrm{MN}>5.0 \phi\end{array}$}} \\
\hline & & $M=$ Medium & & \\
\hline & & $F=$ Fine & & \\
\hline & & $V=$ Very fine & & \\
\hline \multirow{2}{*}{\multicolumn{2}{|c|}{2 levels of TOC: }} & $\mathrm{L}=\mathrm{Low}$ & \multirow{2}{*}{\multicolumn{2}{|c|}{$\begin{array}{l}\text { TOC } \leq 5.0 \% \\
\text { TOC }>5.0 \%\end{array}$}} \\
\hline & & $\mathrm{H}=\mathrm{High}$ & & \\
\hline \multirow{2}{*}{\multicolumn{2}{|c|}{2 levels of $\mathrm{Cr}$ : }} & $\mathrm{L}=\mathrm{Low}$ & \multirow{2}{*}{\multicolumn{2}{|c|}{$\begin{array}{l}\mathrm{Cr} \leq 30.0 \mathrm{ppm} \\
\mathrm{Cr}>30.0 \mathrm{ppm}\end{array}$}} \\
\hline & & $\mathrm{H}=\mathrm{High}$ & & \\
\hline
\end{tabular}

This procedure used reciprocal averaging (Hill 1973) of the relative abundances of the 80 most frequently occurring species (of a total of 357 species collected). We assumed these 80 species were most important to benthic community structure and function and thus most appropriate to examine. The first axis of ordination yielded groups of related strata. The second axis grouped related species. The resulting species groups were similar to but not necessarily the same as the division based upon habitat strata. Data in each stratum/species group were successively ordinated, as much as seemed useful (6 rounds) (Hill 1973, 1979, Hill et al. 1975, Gauch 1982).

\section{RESULTS AND DISCUSSION}

\section{Post-collection stratification}

Our initial attempt to test the validity of the putative indicator taxa, by looking for apparent patterns of significant differences between post-collection stratum means, was inconclusive. The average density and bio- mass of putative indicator taxa from pooled data from all stations assigned to a habitat stratum, defined in Tables $2 \& 3$, are shown in Table 4 . Some clear groupings are evident in the stratified means (Table 4), e.g. the densities and biomasses of the 5 selected benthic indicator species were closely associated with mean grain size (MN) and contaminant levels (TOC and $\mathrm{Cr}$ ). Density and biomass of Ceriantheopsis americanus, Nephtys incisa and Nucula proxima were relatively high in strata defined by finer grain sizes and higher contaminant levels; i.e. Strata 6 (FHL), 8 (VHL), $14(\mathrm{FHH}), 15(\mathrm{VLH})$ and $16(\mathrm{VHH}) . \mathrm{C}$. americanus and $N$. proxima, however, were also relatively abundant in the coarser grain size strata, i.e. Strata 1 (CLL), 3 (MLL) and $12(\mathrm{MHH})$. These strata contained stations that were either near the sewage sludge or dredged material disposal sites or in the upper Hudson Shelf Valley (Table 3, Fig. 1).

Capitella spp. were found in relatively high densities and biomasses at only 2 stations $(6 \& 7)$ in Strata 12 $(\mathrm{MHH})$ and $14(\mathrm{FHH})$ characterized by high TOC and $\mathrm{Cr}(\cdot \mathrm{HH})(\cdot$ indicates for all levels). This species group showed the expected tolerance to highly contaminated, fine sediments and intermittent hypoxic and reducing conditions (Pearson \& Rosenberg 1978) that occur in the Christiaensen Basin. On the other hand, Ceriantheopsis americanus, Nephtys incisa and Nucula proxima are thought to have less tolerance for these conditions (Pearson \& Rosenberg 1978).

Ampelisca agassizi was abundant only at deeper stations characterized by medium to fine grained sediments (Stns 14, 15, 34, 35 \& P13) in Strata 3 (MLL), 5 (FLL), 6 (FHL) and especially 8 (VHL). A. agassizi was never observed in strata with high trace metal levels, i.e. Strata 11 through $16(\cdots \mathrm{H})$. There were low densities and biomasses of total amphipods and crustaceans and fewer total species in strata characterized by higher trace metal concentrations. This relation suggests that $A$. agassizi is indeed an indicator of chemical contamination, apparently sensitive to high levels of metals. This and other species may in fact be responding to other covariates that correlate with unmeasured environmental variables, for example, hypoxia or sulfide. Organic contaminants, such as polycyclic aromatic hydrocarbons (PAHs), pesticides and polychlorinated biphenyls ( $\mathrm{PCBs}$ ) may also be important in determining community structure. $\mathrm{PAH}$ and PCB data were available only for the 1980 survey, however. These organic contaminants data showed a distribution pattern of similar to that found for trace metals (Reid et al. 1982).

The strata means of Table 4 were compared using ANOVA and multiple range tests (Table 5). In most cases, the ANOVA F-statistics were significant above the $95 \%$ level; i.e. stratum means of the putative 
Table 3. Strata, strata groups (A to D) and appropriate station collections used for stratification and classification analysis of New York Bight sediment and benthic macrofaunal species association. The assigned numto be part of a stratum; i.e. 1980,1981 or 1982 respectively. Str.: stratum

\begin{tabular}{|c|c|c|c|c|c|c|c|c|c|c|}
\hline \multirow{3}{*}{$\begin{array}{l}\text { Str. group: } \\
\text { Str. no.: } \\
\text { Str. 'code': }\end{array}$} & A & \multicolumn{4}{|c|}{ B } & \multicolumn{2}{|c|}{$\mathrm{C}$} & \multicolumn{3}{|c|}{ D } \\
\hline & 11 & 1 & 3 & 5 & 8 & 6 & 14 & 12 & 15 & 16 \\
\hline & MLH & CLL & MLL & FLL & VHL & FHL & $\mathrm{FHH}$ & $\mathrm{MHH}$ & VLH & $\mathrm{VHH}$ \\
\hline Stn no. & & & & & & & & & & \\
\hline 10 & --- & $0--$ & $\ldots$ & $\ldots$ & - - & --- & $1--$ & --- & $\ldots$ & --2 \\
\hline 44 & --- & $0-2$ & $-1-$ & $\ldots$ & --- & --- & $\ldots$ & $\ldots$ & -- & - \\
\hline 43 & --- & 01 - & --2 & $\ldots$ & --- & --- & $\ldots$ & --- & --- & $\ldots$ \\
\hline 24 & --- & $01-$ & --2 & -- & -- & --- & -- & -- & --. & $\ldots$ \\
\hline 42 & --- & $-1-$ & $0-2$ & $\ldots$ & $\cdots$ & --- & $\ldots$ & --- & --- & $\ldots$ \\
\hline 17 & -- & -- & $\ldots$ & $\ldots$ & $-\ldots$ & 012 & $=-$ & $=--$ & --- & --- \\
\hline 21 & --- & $-\infty$ & $0--$ & $-1-$ & --- & --- & - & --- & --- & --- \\
\hline 32 & $\ldots$ & $\ldots$ & 012 & --- & --- & --- & --- & -.- & --- & $\ldots$ \\
\hline 34 & --- & - - - & $0-2$ & $\ldots$ & - - & --- & $\ldots$ & --- & --- & $\ldots$ \\
\hline 29 & -.- & $\ldots$ & 012 & $-\ldots$ & $\ldots$ & --- & - & --_ & --_ & $-\cdots$ \\
\hline 30 & --- & --- & 012 & $\ldots$ & $\ldots$ & --- & -- & --- & --- & -.. \\
\hline 7 & --_ & --_ & $01-$ & --- & - & -... & -.. & --2 & - - & $\ldots$ \\
\hline 20 & --_ & - - & $0--$ & $-1-$ & - - & - & $\ldots$ & -.- & -- & -- \\
\hline 19 & --2 & -- & $0--$ & --- & $\ldots$ & $-\ldots$ & -.. & --- & --- & -- \\
\hline 38 & --- & --- & 012 & $\ldots$ & -- & --- & -- & $\ldots$ & -- & $\ldots$ \\
\hline 37 & --- & --- & 012 & - - & $\ldots$ & --- & $\ldots$ & $\ldots$ & -- & $\ldots$ \\
\hline 23 & --- & --- & 012 & $\ldots$ & $-\ldots$ & --- & $\ldots$ & - & - - & $\ldots$ \\
\hline 26 & --- & --- & 012 & $\ldots$ & --- & --- & $\ldots$ & $\ldots$ & --- & -- \\
\hline 27 & --- & --- & 012 & --- & $-\infty$ & --- & --- & -- & --- & $\ldots$ \\
\hline 25 & -- & --- & $0--$ & $-1-$ & -- & $\ldots$ & -- & --- & --- & -- \\
\hline 41 & --- & --- & 012 & --- & $-\cdots$ & --- & $\ldots$ & -- & --- & -- \\
\hline 33 & -- & --- & -12 & $0--$ & $\cdots$ & --- & --- & $-\cdots$ & --- & $\ldots$ \\
\hline 36 & $-\ldots$ & --- & -12 & --- & $0--$ & --- & $-\cdots$ & -- & $\ldots$ & $\ldots$ \\
\hline 4 & -..- & --- & -12 & - & $\ldots-$ & $0--$ & --- & $-\cdots$ & $\ldots$ & - - \\
\hline 34 & -- & --- & --2 & $-1-$ & $0=$ & --- & --- & --- & $\ldots$ & - - \\
\hline 40 & -.. & --- & --2 & --- & $\ldots$ & --- & $-1-$ & -- & --- & $\ldots$ \\
\hline 12 & -- & --- & --2 & $-1-$ & -- & $0--$ & --- & $\ldots$ & $-\ldots-$ & $\ldots$ \\
\hline 28 & -.. & $\ldots$ & --2 & $01-$ & $\ldots$ & --- & -.- & -- & --- & - - \\
\hline 18 & $\ldots$ & - & -- & --- & --- & --- & --- & --2 & --- & $-1-$ \\
\hline 22 & $\ldots$ & - & $\ldots$ & 012 & --- & --- & --- & --- & --- & --- \\
\hline 14 & -- & -- & --- & $0-2$ & $-\cdots$ & $-1-$ & --- & --- & --- & --- \\
\hline 21 & --- & $\ldots$ & --- & -12 & $\ldots$ & --- & $0--$ & --- & --- & --- \\
\hline 35 & --- & --- & -- & -12 & $0 \ldots$ & --- & $\ldots$ & $\ldots$ & $\ldots$ & --- \\
\hline 1 & $-\cdots$ & -- & --- & -12 & $\ldots$ & $0--$ & $\ldots$ & --- & --- & $\ldots$ \\
\hline 8 & --- & --- & --- & --2 & $\cdots$ & -- & -- & -- & -- & $0--$ \\
\hline 16 & --- & --- & $\ldots$ & --- & $\ldots$ & $0--$ & --2 & -- & --- & $\cdots$ \\
\hline 3 & --- & $-\cdots$ & -- & $\ldots$ & $\cdots$ & -12 & $0--$ & --- & --- & $\ldots$ \\
\hline 13 & $\ldots$ & $\ldots$ & $\ldots$ & $-\infty$ & $0=-$ & $-1-$ & --2 & -- & --- & --- \\
\hline 5 & -- & -- & $\ldots$ & $\ldots$ & $-1-$ & --- & --2 & --- & --- & $0--$ \\
\hline 9 & --- & -.- & $\ldots$ & --- & $\ldots$ & --- & $0-2$ & --- & $-1-$ & -- \\
\hline 1 & -- & $\ldots$ & $\ldots$ & -- & $\ldots$ & --- & $0-2$ & --- & --- & $\ldots$ \\
\hline 2 & -- & $\ldots$ & $\ldots$ & $\ldots$ & $\ldots$ & --- & $0-2$ & -- & --- & -- \\
\hline 6 & --- & --- & $\ldots$ & $\ldots$ & $\ldots$ & --- & $-1-$ & --- & --- & --- \\
\hline 158 & --- & --- & $-1-$ & $\ldots$ & $\ldots$ & $\ldots$ & $\ldots$ & -- & --- & $\ldots$ \\
\hline P13 & -- & $\ldots$ & $-1-$ & $0--$ & $\ldots$ & --- & $\ldots$ & $\ldots$ & --- & --- \\
\hline 63 & --- & $\ldots-$ & $-1-$ & --- & $\ldots$ & --- & $-\cdots$ & $-\cdots$ & --- & $\ldots$ \\
\hline 64 & -- & - & $-1-$ & --- & --- & --- & --- & -.- & $-\ldots-$ & --- \\
\hline
\end{tabular}
bers 0,1 or 2 for station collection refer to the year collection was defined

stratum. The multiple range test for $A$. agassizi was performed only for those strata where the species was found (Strata 3, 5, 6 \& 8), even though the overall F-statistic was non-significant.

The strata analyses confirm the putative strong associations between sediment characteristics and 'indicator' taxa. Ceriantheopsis americanus, Nephtys incisa and Nucula proxima appear to be reasonable indicators of fine sediment and high TOC, but are not sensitive to trace metal levels. Capitella spp., as expected, were indicators of high TOC and trace metal sediment contamination. Crustaceans, including Ampelisca agassizi and other amphipods, and overall species density are indicators of minimally contaminated habitats. These associations were not statistically clear cut in all cases, however.

\section{Associations by correlation analysis}

The correlation matrix (Table 6) generated for the 23 transformed, unstratified variables indicated that sediment chemical variables (TOC, TKN and metals) correlated well with physical characteristics (MN and GS). Correlations were strong ( $\mathrm{r}=0.94$ to 0.98 ) between metals ( $\mathrm{Cr}, \mathrm{Pb}$ and $\mathrm{Zn}$ ) and moderately strong ( $r=0.73$ to 0.75 ) between TOC and the 3 metals. TOC and TKN were moderately correlated $(r=0.70)$. Sediment grain size variables (MN and GS) were not strongly correlated with density or biomass of some selected taxa, with $|r|$ being typically $<0.7$. Correlations between sediment contaminants and Capitella spp. were weak but positive, while correlations between sediment contaminants and Ampelisca agassizi, all amphipods, and all crustaceans were weak and negative. Stronger correlations between all sediment variables and Ceriantheopsis americanus, Nephtys incisa and Nucula proxima were found. Correlations were strong among the indicator species $C$. americanus, $N$. incisa and $N$. proxima, but correlations of $A$. agassizi with other indicator species were weak and, as expected, negative, while those for Capitella spp. and other species were weak and generally positive.

indicator taxa were, in some way, significantly different. Only numbers and biomass of Ampelisca agassizi and total species, and biomass of amphipods and crustaceans, were not significantly different between
Using this correlation matrix, unrotated factor analysis reduced the 23 original sediment and biological variables to 6 factors with eigenvalues greater than 1.0 (Table 7). Factor loadings (coefficients of 
Table 4. Average density and biomass of selected benthic macrofaunal taxa. Str.: Stratum; C. amer: Ceriantheopsis americanus; N. inci. Nephtys incisa; Capit.: Capitella spp.; N. prox.. Nucula proxima; A. agas.. Ampelisca agassizi

\begin{tabular}{|c|c|c|c|c|c|c|c|c|c|}
\hline \multirow[t]{2}{*}{ Str } & \multirow{2}{*}{$\begin{array}{l}\text { Sample } \\
\text { size }\end{array}$} & \multicolumn{5}{|c|}{ Indicator species } & \multirow{2}{*}{$\begin{array}{l}\text { No. of } \\
\text { amphipod } \\
\text { spp. }\end{array}$} & \multirow{2}{*}{$\begin{array}{c}\text { No. of } \\
\text { crustacean } \\
\text { spp. }\end{array}$} & \multirow{2}{*}{$\begin{array}{l}\text { No. of } \\
\text { all } \\
\text { spp. }\end{array}$} \\
\hline & & C. amer. & $N$. inci. & Capit. & N. prox. & A. agas. & & & \\
\hline \multicolumn{10}{|c|}{ Density (no. per $0.1 \mathrm{~m}^{2}$ ) } \\
\hline 1 & 9 & 0.3 & 0.0 & 4.2 & 373.3 & 0.0 & 1.4 & 3.4 & 27.1 \\
\hline 3 & 55 & 1.7 & 0.4 & 2.4 & 29.8 & 44.9 & 7.1 & 11.2 & 42.8 \\
\hline 5 & 21 & 2.1 & 0.8 & 4.4 & 82.1 & 193.8 & 6.6 & 10.5 & 43.6 \\
\hline 6 & 12 & 8.8 & 20.7 & 3.0 & 211.4 & 158.2 & 4.8 & 9.3 & 45.9 \\
\hline 8 & 5 & 8.2 & 20.0 & 0.6 & 345.0 & 771.4 & 9.0 & 14.0 & 55.2 \\
\hline 11 & 1 & 0.0 & 0.0 & 1.0 & 6.0 & 0.0 & 2.0 & 5.0 & 33.0 \\
\hline 12 & 2 & 16.0 & 6.5 & 341.5 & 2015.5 & 0.0 & 2.5 & 4.0 & 42.5 \\
\hline 14 & 19 & 19.9 & 83.7 & 62.6 & 1453.6 & 0.0 & 1.8 & 4.1 & 33.2 \\
\hline 15 & 1 & 32.0 & 18.0 & 2.0 & 547.0 & 0.0 & 0.0 & 0.0 & 29.0 \\
\hline 16 & 4 & 32.0 & 91.0 & 0.0 & 2.373 .3 & 0.0 & 0.8 & 2.3 & 32.5 \\
\hline \multicolumn{10}{|c|}{ Biomass (mg per $0.1 \mathrm{~m}^{2}$, wet wt) } \\
\hline 1 & 9 & 113.3 & 0.0 & 4.2 & 247.3 & 0.0 & 13.4 & 297.6 & 4560.1 \\
\hline 3 & 55 & 210.9 & 5.6 & 1.6 & 104.2 & 60.1 & 887.7 & 1106.9 & 21635.3 \\
\hline 5 & 21 & 117.2 & 43.1 & 4.1 & 168.2 & 331.9 & 1137.3 & 6301.0 & 28692.6 \\
\hline 6 & 12 & 1141.4 & 2089.1 & 2.7 & 401.8 & 308.5 & 1220.4 & 3354.6 & 27514.7 \\
\hline 8 & 5 & 292.4 & 1296.2 & 1.0 & 28674 & 1154.4 & 2027.0 & 2155.0 & 65211.8 \\
\hline 11 & 1 & 0.0 & 0.0 & 1.0 & 5.0 & 0.0 & 10.0 & 20.0 & 7709.0 \\
\hline 12 & 2 & 1447.0 & 145.0 & 958.0 & 3807.5 & 0.0 & 11.5 & 302.0 & 18490.5 \\
\hline 14 & 19 & 1697.8 & 2165.1 & 156.6 & 7686.4 & 0.0 & 22.2 & 82.5 & 39780.1 \\
\hline 15 & 1 & 3430.0 & 5330.0 & 1.0 & 6670.0 & 0.0 & 0.0 & 0.0 & 23471.0 \\
\hline 16 & 4 & 2445.8 & 1986.3 & 0.0 & 29769.3 & 0.0 & 1.0 & 83.0 & 38763.0 \\
\hline
\end{tabular}

correlation between the factors and the original variables) express the relative contributions of the original variables to the derived factors. Using a correlation (loading) of 0.6 or greater to indicate a strong contribution to a factor, it is evident that Factor 1 was mostly influenced by sediment variables as well as density and biomass of Ceriantheopsis americanus, Nephtys incisa and Nucula proxima. Factor 1 explained $48 \%$ of the total variance of the original measures. Factor 2 explained another $24 \%$ of the total variance and was influenced mainly by density and biomass of Ampelisca agassizi, all amphipods, all crustaceans, and overall number of species. Factor 3 contained an additional $11 \%$ of the total variance and was influenced mainly by Capitella spp. abundance. Factors 1 through 3 accounted for $83 \%$ of the total variance explained by these factors. The rotated (varimax) factor analysis (not presented) yielded similar results for both the factor loadings and the associations between the variables comprising each factor, although contributions toward total variance explained were somewhat more evenly spread over the factors.

Communality coefficients represent the extent of overlap between the original variables and the principal factors and were high $(0.77$ to 0.98$)$ for the entire range of variables (Table 7). A communality of 1.0 indicates the variable is completely explained by the principal factors, while a communality of 0.0 indicates all factor loadings are 0.0 and the variable is totally independent of any of the factors. Thus, the original variables are well explained by the principal factors (Table 7 ).

In the canonical correlation analysis, sediment and biological variables were combined, since solutions for separate factor analyses of sediment and faunal groups (not presented here) were similar to those shown for the combined variables (Table 7). The canonical solution maximizes the correlation between new (reduced) variables (called canonical variates as opposed to factors) generated for the domain of sediment and faunal variables. Vanate 1 showed that all sediment variables (with TKN to a lesser degree), all measures of Nepthys incisa and Nucula proxima and density of Ceriantheopsis americanus were strongly and positively associated (Table 8 ). Variate 2 indicated that all species and amphipod measures and crustacean density were strongly associated. Ampelisca agassizi associated with this group to a lesser degree, as did Capitella spp., but with opposite signs (Table 8). The first 2 variates accounted for most of the original variables.

Canonical correlations between the first 2 pairs of canonical variates were 0.93 and 0.72 indicating a strong intercorrelation (Table 8 ). Chi-square values 
Table 5. Results of ANOVA and Tukey's multiple range tests for density and biomass of selected benthic macrofaunal taxa;

- significant differences among strata at the $95 \%$ level (ANOVA); the pair of numbers in parentheses show strata that were significantly different at $95 \%$ level in the multiple range tests

\begin{tabular}{|c|c|c|c|c|c|c|c|}
\hline C. amer. & N. inci. & $\begin{array}{l}\text { Indicator species } \\
\text { Capit. }\end{array}$ & N. prox. & A. agas. & $\begin{array}{l}\text { No. of amphi- } \\
\text { pod spp. }\end{array}$ & $\begin{array}{l}\text { No. of crusta- } \\
\text { cean spp. }\end{array}$ & $\begin{array}{l}\text { No. of } \\
\text { all spp. }\end{array}$ \\
\hline \multicolumn{8}{|c|}{ Density (no. per $0.1 \mathrm{~m}^{2}$ ) } \\
\hline $10.88^{\circ}$ & $19.63^{\circ}$ & $4.11^{\circ}$ & $11.72^{\circ}$ & \multirow{13}{*}{$\begin{array}{l}1.70 \\
(3,8)\end{array}$} & $3.14^{\circ}$ & \multirow{13}{*}{$\begin{array}{l}3.16^{\circ} \\
(3.14)\end{array}$} & \multirow[t]{13}{*}{1.73} \\
\hline$(1,14)$ & $(1,14)$ & $(1,12)$ & $(1,16)$ & & $(3,14)$ & & \\
\hline$(1,16)$ & $(1,16)$ & $(3,12)$ & $(3,14)$ & & & & \\
\hline$(3,14)$ & $(3,14)$ & $(5,12)$ & $(3,16)$ & & & & \\
\hline$(3,16)$ & $(3,16)$ & $(6,12)$ & $(5,14)$ & & & & \\
\hline$(5,14)$ & $(5,14)$ & $(8,12)$ & $(5,16)$ & & & & \\
\hline$(5,16)$ & $(5,16)$ & $(11,12)$ & $(6,14)$ & & & & \\
\hline$(6,16)$ & $(6,14)$ & $(12,14)$ & $(6,16)$ & & & & \\
\hline \multirow[t]{5}{*}{$(8,16)$} & $(6,16)$ & $(12,15)$ & $(8,16)$ & & & & \\
\hline & $(8,14)$ & $(12,16)$ & & & & & \\
\hline & $(8,16)$ & & & & & & \\
\hline & $(12,14)$ & & & & & & \\
\hline & $(12,16)$ & & & & & & \\
\hline \multicolumn{8}{|c|}{ Biomass (mg per $0.1 \mathrm{~m}^{2}$ ) } \\
\hline $5.54^{\circ}$ & $14.72^{\circ}$ & $3.58^{\circ}$ & $12.20^{\circ}$ & \multirow{16}{*}{$\begin{array}{l}1.78 \\
(3,8)\end{array}$} & 1.34 & \multirow[b]{16}{*}{ abbreviations } & \multirow[b]{16}{*}{ Table 4} \\
\hline$(1,14)$ & $(1,6)$ & $(1,12)$ & $(1,16)$ & & & & \\
\hline$(1,16)$ & $(1,14)$ & $(3,12)$ & $(3,14)$ & & & & \\
\hline$(3,14)$ & $(1,15)$ & $(5,12)$ & $(3,16)$ & & & & \\
\hline$(3,16)$ & $(1,16)$ & $(6,12)$ & $(5,16)$ & & & & \\
\hline$(5,14)$ & $(3,6)$ & $(8,12)$ & $(6,16)$ & & & & \\
\hline \multirow[t]{10}{*}{$(5,16)$} & $(3,14)$ & $(12,14)$ & $(8,16)$ & & & & \\
\hline & $(3,15)$ & $(12,16)$ & $(11,16)$ & & & & \\
\hline & $(3,16)$ & & $(12,16)$ & & & & \\
\hline & $(5,6)$ & & $(14,16)$ & & & & \\
\hline & $(5,14)$ & & & & & & \\
\hline & $(5,15)$ & & & & & & \\
\hline & $(5,16)$ & & & & & & \\
\hline & $(8,15)$ & & & & & & \\
\hline & $(11,15)$ & & & & & & \\
\hline & $(12,15)$ & & & & "See species abbreviations in Table 4 & & \\
\hline
\end{tabular}

from Bartlett's (1947) test confirmed the significance ( $\alpha=0.05$ ) of the correlations. This suggests that abundances of the 5 putative macrofaunal indicator taxa and the selected sediment variables were highly interdependent.

The results from correlation analysis thus support previously reported ecological associations. For example, Nephtys incisa, Nucula proxima and Ampelisca agassizi are reported to be members of a benthic community commonly found in the silty sands of southern New England estuaries and coastal areas (Pratt 1973, Steimle 1982, Caracciola \& Steimle 1983). Ceriantheopsis americanus can also be considered part of that community, but is not usually as abundant elsewhere as it is in the New York Bight apex. The analytical groupings suggest that $A$. agassizi, although common in the same southern New England habitats as the other species, may be sensitive to the contaminated sediments of the Bight apex. The analyses also suggest overall crustacean density as being sensitive to chemical contamination as it is relatively low in the apex. Segregation of Capitella spp. from the other taxa agrees with reports of its being pollution-tolerant, but a weak competitor, abundant mostly in highly stressed environments that exclude most other species (Pearson \& Rosenberg 1978).

\section{Associations by classification analysis}

Associations between a large faunal array (the 80 most frequently collected species) and the 10 sediment (habitat) strata defined in Table 2 were examined using a classification with ordination procedure of double reciprocal averaging. For this analysis, the strata were classified into 2 , then 4 groups, and the average within-stratum densities of the 80 species were assigned relative abundance codes ranging from 1 to 9 (Table 9). These codes are as such: 
n|

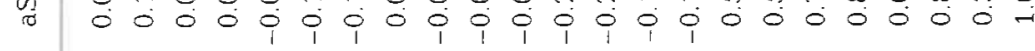

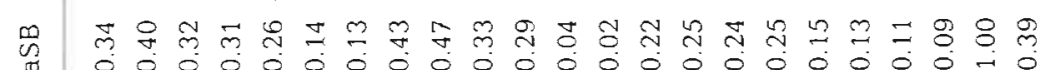

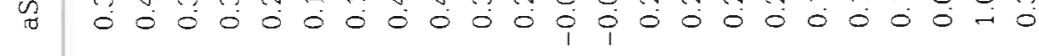

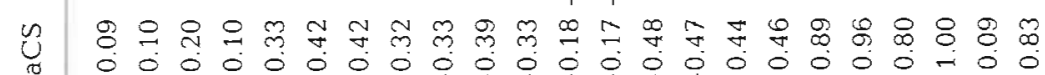

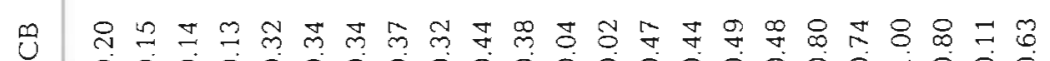

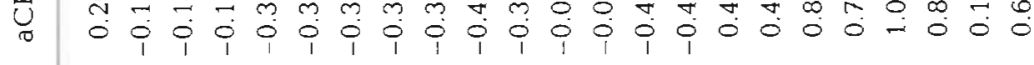
幽

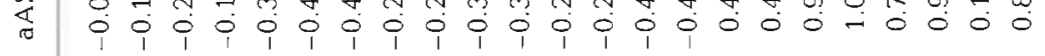
m $\rightarrow$ 육 đ

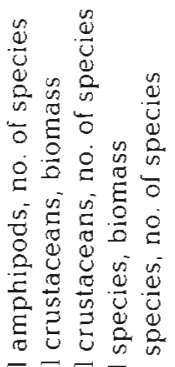
$\overline{\bar{\sigma}} \overline{\bar{\sigma}} \overline{\bar{\sigma}} \overline{\bar{\sigma}}$

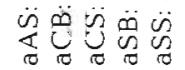

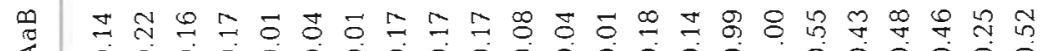

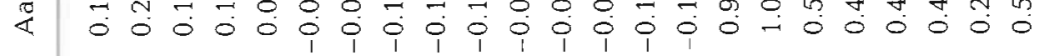

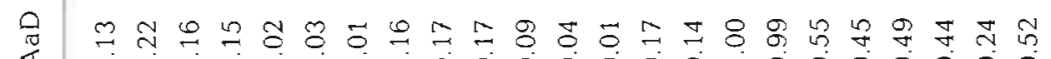

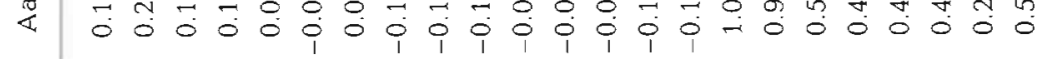

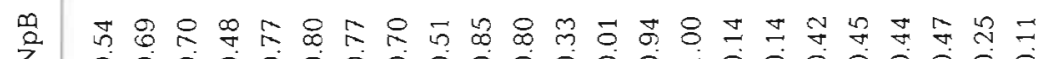
Z

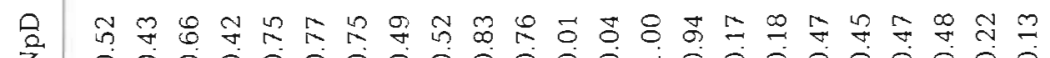

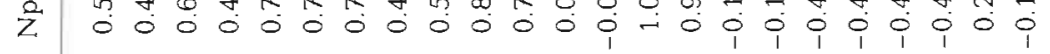
บ

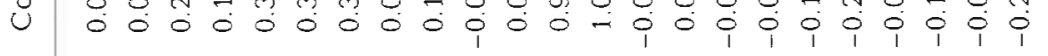

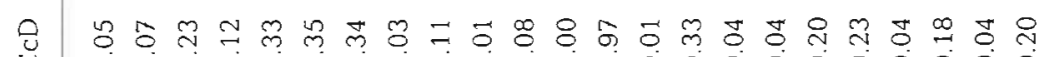

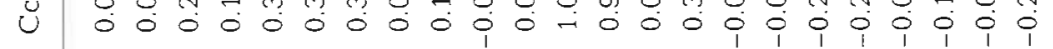

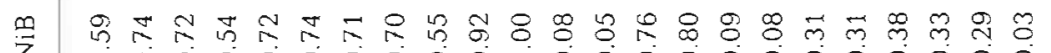

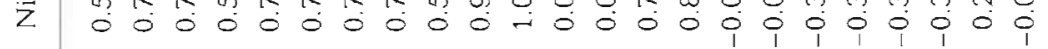

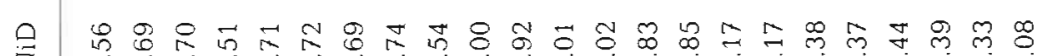

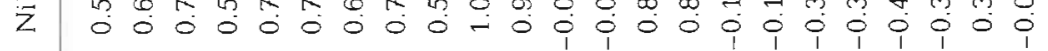
m

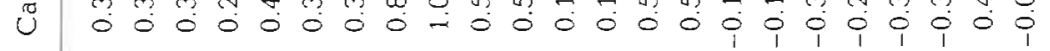

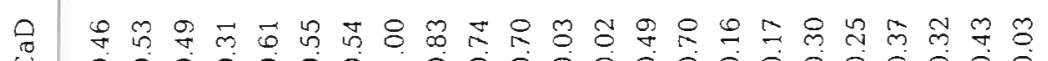

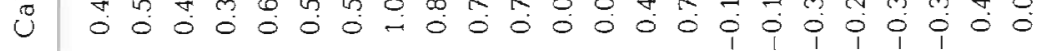

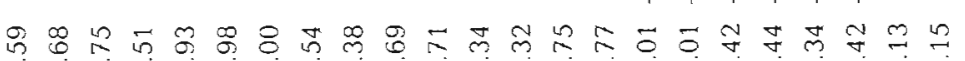
4

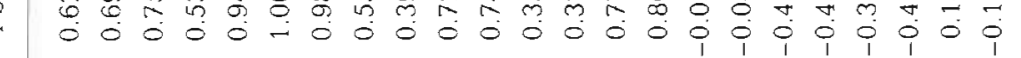
ப

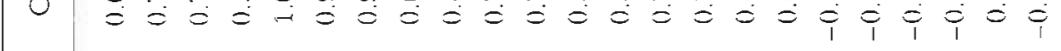

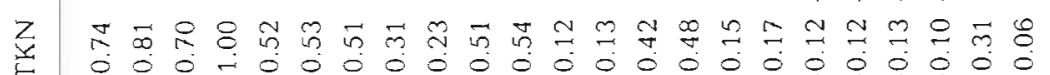

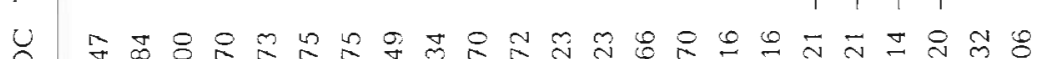

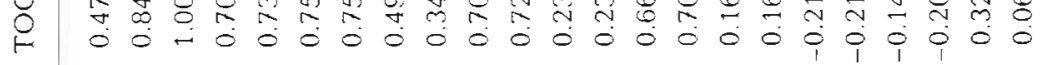

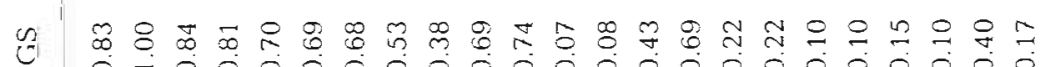

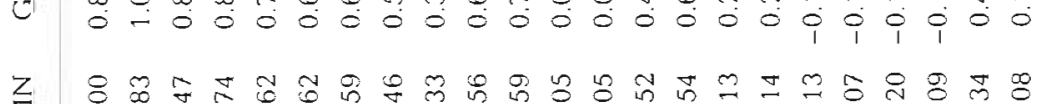
Z \begin{tabular}{l}
$Z$ \\
\hline
\end{tabular}

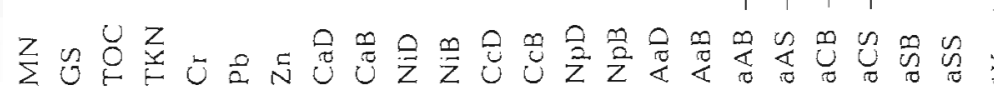

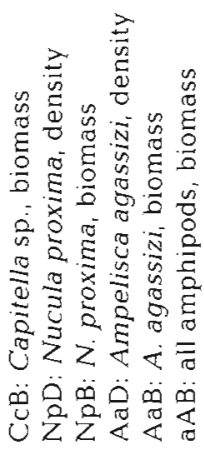

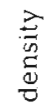

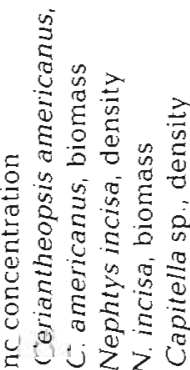

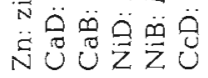

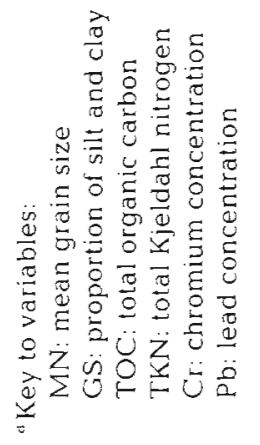


Table 7. Factor loadings or correlations of factors with original benthic habitat and macrofaunal variables, and communality indices. D.. density; B.: biomass; N.: number

\begin{tabular}{|c|c|c|c|c|c|c|c|}
\hline \multirow[t]{2}{*}{ Variable } & \multicolumn{6}{|c|}{ Factor } & \multirow[t]{2}{*}{ Communality } \\
\hline & 1 & 2 & 3 & 4 & 5 & 6 & \\
\hline Mean grain size & 0.671 & 0.420 & 0.005 & -0.245 & -0.036 & 0.352 & 0.8119 \\
\hline Silt and clay & 0.761 & 0.510 & 0.011 & -0.204 & -0.021 & 0.219 & 0.9301 \\
\hline Total organic C & 0.784 & 0.384 & 0.165 & -0.140 & -0.048 & 0.054 & 0.8149 \\
\hline Total Kjeldahl N & 0.500 & 0.380 & 0.084 & -0.412 & -0.027 & 0.572 & 0.8972 \\
\hline Chromium & 0.869 & 0.202 & 0.207 & 0.033 & -0.116 & -0.197 & 0.8912 \\
\hline Lead & 0.892 & 0.111 & 0.246 & -0.066 & -0.148 & -0.217 & 0.9416 \\
\hline Zinc & 0.877 & 0.117 & 0.264 & -0.081 & -0.114 & -0.274 & 0.9314 \\
\hline Ceriantheopsis americanus, D. & 0.743 & 0.115 & -0.313 & 0.445 & 0.089 & -0.003 & 0.8687 \\
\hline Ceriantheopsis americanus, $\mathrm{B}$. & 0.606 & 0.025 & -0.241 & 0.582 & 0.276 & 0.125 & 0.8569 \\
\hline Nephtys incisa, D. & 0.873 & 0.111 & -0.256 & 0.058 & -0.089 & -0.074 & 0.8558 \\
\hline Nephtys incisa, B. & 0.858 & 0.187 & -0.155 & 0.067 & -0.104 & -0.067 & 0.8140 \\
\hline Capitella sp., D. & 0.227 & -0.123 & 0.872 & 0.351 & -0.068 & 0.092 & 0.9636 \\
\hline Capitella sp., B. & 0.207 & -0.106 & 0.882 & 0.343 & -0.027 & 0.126 & 0.9673 \\
\hline Nucula proxima, D. & 0.885 & 0.027 & -0.226 & -0.016 & -0.070 & -0.222 & 0.8889 \\
\hline Nucula proxima, B. & 0.903 & 0.071 & -0.188 & -0.028 & -0.069 & -0.197 & 0.8992 \\
\hline Ampelisca agassizi, D. & -0.186 & 0.738 & 0.251 & -0.217 & 0.468 & -0.268 & 0.9808 \\
\hline Ampelisca agassizi, B. & -0.188 & 0.741 & 0.250 & -0.219 & 0.471 & -0.251 & 0.9801 \\
\hline All amphipods, B. & -0.584 & 0.772 & -0.030 & 0.111 & -0.158 & -0.031 & 0.9016 \\
\hline All amphipods, N. & -0.574 & 0.714 & -0.115 & 0.159 & -0.256 & 0.042 & 0.9450 \\
\hline All crustaceans, B. & -0.563 & 0.614 & 0.158 & 0.141 & -0.145 & -0.076 & 0.7717 \\
\hline All crustaceans, N. & -0.587 & 0.711 & -0.031 & 0.129 & -0.305 & 0.023 & 0.9595 \\
\hline All species, B. & 0.288 & 0.487 & -0.181 & 0.399 & 0.410 & 0.273 & 0.7547 \\
\hline All species, $N$. & -0.244 & 0.833 & -0.166 & 0.220 & -0.197 & -0.080 & 0.8750 \\
\hline Eigenvalue & 9.865 & 4.827 & 2.304 & 1.456 & 1.029 & 1.010 & \\
\hline$\%$ Variance & 48.120 & 23.550 & 11.240 & 7.150 & 5.020 & 4.930 & \\
\hline
\end{tabular}

Code \# 1 = species occurrence in a stratum, but with an average density of less than 1.0 per $0.1 \mathrm{~m}^{2}$,

Code $\# 2$ = average densities from 1 to $<5$,

Code \# 3 = average densities from 5 to $<10$,

Code \# 4 = average densities from 10 to $<20$,

Code \# 5 = average densities from 20 to $<50$,

Code \# 6 = average densities from 50 to $<100$,

Code $\# 7$ average densities from 100 to $<200$,

Code \# 8 = average densities from 200 to $<500$, and

Code \# 9 average densities $\geq 500$ individuals.

The density cutoff points are somewhat arbitrary and not truly proportional, but are based roughly on the distribution of mean densities. Both the 'Stratum classification' (columns) and 'Species classification' (rows) must be considered in Table 9 to maximize the information from the analysis.

\section{Species associations with habitat types}

For stratum classification, the 10 original sediment strata (Table 3 ) were reduced by 2 -round ordination to 4 strata groups, A to D, as indicated by codes from ordination results with the presence of either $\mathrm{a}^{\prime} 0$ ' or $\mathrm{a}$ ' 1 ' in
'Classification for stratum' (Table 9). In the first round of ordination for strata, 2 groups, AB (e.g. as indicated by '0 0000' in 'Classification code for stratum') and CD (e.g. '11 111' in 'Classification code for stratum') were formed. Further, the second round of ordination separated these $A B$ and $C D$ into strata group $A$ (e.g. ' 0 ' in 'Classification code for stratum'), strata group B (e.g. '1111' in 'Classification code for stratum'), strata group $C$ (e.g. '00' in 'Classification code for stratum') and strata group D (e.g. '111' in 'Classification code for stratum'). Group A includes only Stratum 11, characterized as MLH. Group B includes 4 strata with low $\mathrm{Cr}$ levels ( $\cdots$ L): Strata 1 (CLL), 3 (MLL), 5 (FLL) and 8 (VHL). Group C includes 2 strata, Strata 6 (FHL) and 14 $(\mathrm{FHH})$, characterized by fine grain sediments with high TOC levels (FH*). Group D includes 3 strata with high Cr levels $(\cdots \mathrm{H})$ : Strata 12 (MHH), 15 (VLH) and 16 (VHH).

Strata group A (Stratum 11) actually represents a collection at a single station (19) sampled in 1982 (Table 3). It includes species associated with coarser sediment, low to moderate TOC levels (less than $5.0 \%$ ) and unexpectedly high concentrations of metal contaminants ( $\mathrm{Cr}>30.0 \mathrm{ppm}$ ). Twenty-five of the 80 species occurred in this strata group. None were very 
Table 8. Canonical loadings or correlations of canonical variates with original benthic habitat and macrofaunal variables and outcomes of Bartlett's tests with canonical correlations. D.: Density; B.: biomass; N.: number

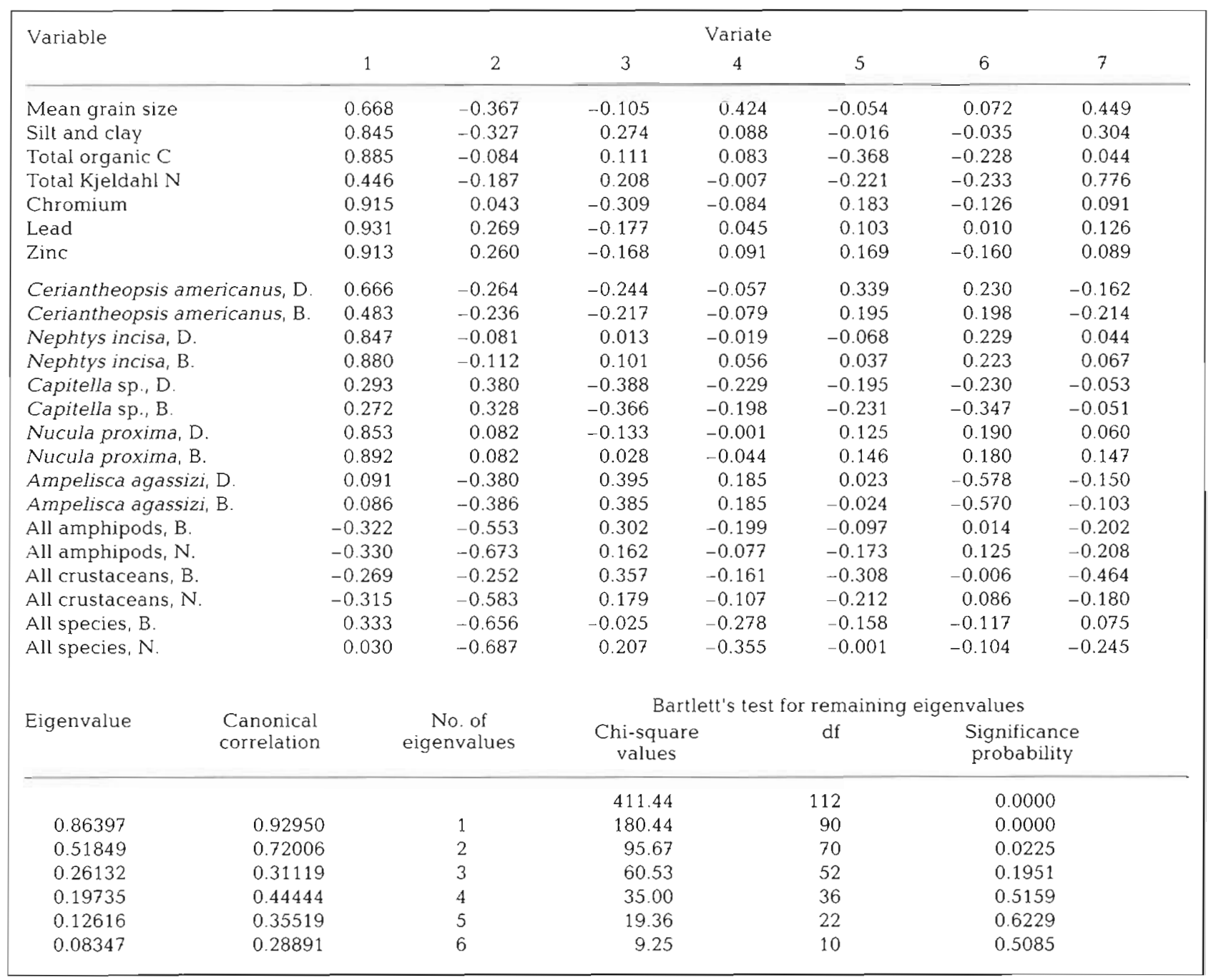

common (average density less than 20 ind. per $0.1 \mathrm{~m}^{2}$, Code \# $\leq 4$ ) but the group included both contaminantsensitive and insensitive species. This station collection may represent an unusual or anomalous situation. The station was well inshore and possibly influenced by a local contaminant source, e.g. a sewer outfall or shipwreck, which could explain the unexpectedly high trace metal levels found in such coarse sediment.

Strata group B includes samples from 40 of the 47 stations from 1 or more of the years sampled (see Table 3) and contains all 80 species in at least 1 of the 4 strata in the group (Table 9). Because all 80 species and most of the stations occur in this group, it is likely this strata group defines a basic, major habitat of benthic macrofaunal organisms in the New York Bight. All strata in this group have low levels of sediment chemical contaminants, with the single exception of high TOC in Stratum 8 . The stations con- stituting this group were mostly in areas outside the Hudson Shelf Valley. For example, Stratum 1 includes stations $(10,24 \& 42$ to 44 , Table $3 \&$ Fig. 1$)$ along the New Jersey coast. Strata 3 and 5 include a widely distributed group of stations from areas off both New Jersey and Long Island (Fig. 1, Table 3). Stratum 8 includes offshore Stns 34 to 36 , plus Stns 5 and 13 in the Bight apex (Table $3 \&$ Fig. 1). The species that were especially common $\left(\geq 20\right.$ per $0.1 \mathrm{~m}^{2}$; i.e abundance Code \# $\geq 4$ ) would seem to be the basic, dominant infauna of the Bight. Included in this group were the polychaetes: Goniadella gracilis, Exogone hebes, Amastigos caperatus, Acesta catherinae, Scoletoma hebes, Tharyx acutus and Monticellina dorsobranchialis; amphipods: Corophium crassicome, Erichthonius fasciatus, Unciola sp. and Leptocheirus pinguis; the sand dollar Echinarachnius parma; and the nut clam Nucula proxima. 
Table 9. Classification analysis for the 80 most common benthic macrofaunal species in the New York Bight. Numbers under the stratum columns (under headings $A$ to $D$ ) are relative abundance code (Code \# 1 to 9 , see text for ranges); (-) species not found in the stratum

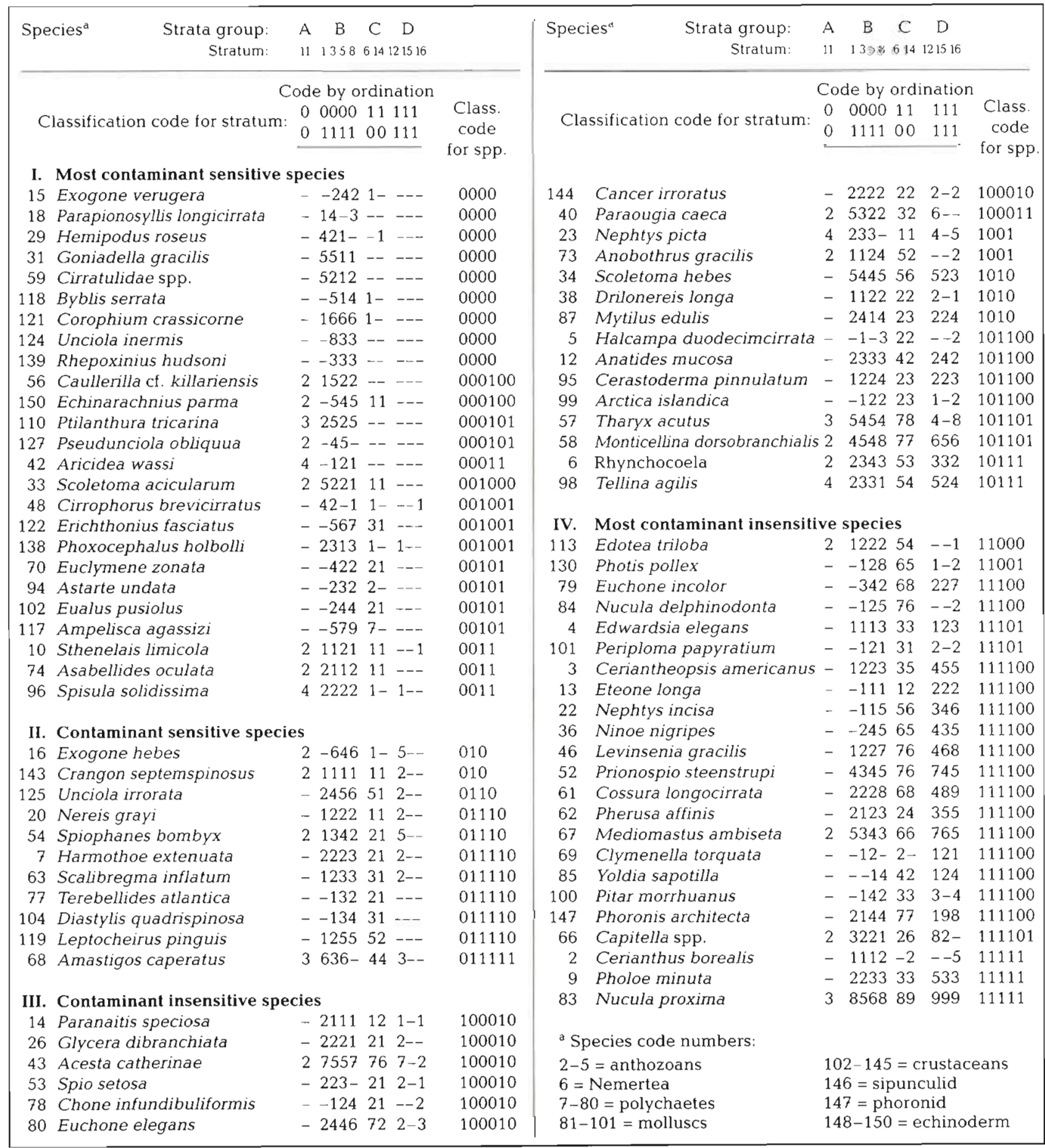

Strata group C includes stations within Strata 6 and 14. Stratum 6 stations $(4 \& 11$ to 17 , see Table 3 \& Fig. 1) were generally in the mid Hudson Shelf Valley and adjacent to the disposal sites in the apex, but not in the Christiaensen Basin. Stratum 14 stations, however, were generally in the Christiaensen Basin area (Stns 1 to $3,5,6,9 \& 10$ ) and the upper Hudson Shelf Valley (Stns 13, $16 \&$ 21, Table 3 \& Fig. 1). The dominant 
species in this group ( $\geq 20$ per $0.1 \mathrm{~m}^{2}$; i.e. abundance Code \# $\geq 4$ ) were those that are considered typical of silty habitats, e.g. the nut clams Nucula spp. and northern dwarf tellin Tellina agilis; the polychaetes Nephtys incisa, Tharyx acutus, Monticellina dorsobranchialis, Acesta catherinae, Scoletoma hebes, Ninoe nigripes, Levinsenia gracilis, Prionospio steenstrupi, Cossura longocirrata, and Mediomastus ambiseta; the phoronid Phoronis architecta; the isopod Edotea triloba; and amphipods Photis pollex and Ampelisca agassizi (Stn 6, Table 9). Many of these species appear well adapted to a wide range of sediment types, although they are most common in silty sand and mud, while some species (but not the most abundant species in this group) belonging to this stratum group may be dependent on sediment type.

Strata group D, including Strata $12(\mathrm{MHH}), 15$ (VLH) and 16 (VHH) (Table 3), is characterized by high concentrations of both TOC and metals. The lone exception is Stratum 15, with low TOC levels; Stratum 15 includes only 1 station collection (Table 3 ) and is possibly another anomaly. The 6 stations comprising this group (Stns 5,7 to 10 \& 18, Table 3 \& Fig. 1) were tightly clustered within the Christiaensen Basin and dredge spoil disposal area. Most dominant species in this group $\left(\geq 20\right.$ per $0.1 \mathrm{~m}^{2}$; i.e. abundance Code \# $\geq 4$ ) were the same as those in strata group $C$, and few additional species occurred frequently in strata group $D_{i}$ Ceriantheopsis americanus, Pholoe minuta, Pherusa affinis and Nephtys picta

Strata groups C and D, which appear closely related, represent the most contaminated habitat conditions in the area, considering strata group A as an anomaly. The most abundant species found in these groups presumably have high tolerance levels for the contaminants examined (Table 9). The main differences in habitat conditions between these 2 groups were consistently high Cr levels for group D and uniformly fine mean grain sizes for group $C$. Species with high occurrence in group $\mathrm{C}$ appear to be more sensitive to sediment grain size than species that are common in group D. Strata group D, as a separate group, is tentative because it consists of data from only 7 collections.

Species that prefer coarser sediments, but can also tolerate contaminants, are abundant in strata group $A_{\text {, }}$ although this group is probably an anomaly, as discussed previously. Strata group B appears to be the basic habitat/benthic macrofaunal community for most of the New York Bight outside the Christiaensen Basin/Hudson Shelf Valley (a depositional sink for fine sediments and anthropogenic contaminants). Some species in this group appear tolerant of higher levels of contaminants (trace metals and/or TOC), occurring in relatively high abundance $\geq 20$ per $0.1 \mathrm{~m}^{2}$; i.e. abundance Code $\# \geq 4$ ) in contaminated strata groups $A, C$ and/or D, e.g. Acesta catherinae, Euchone elegans, Scoletoma hebes, Tharyx acutus, Photis pollex, Nucula delphinodonta and $N$. proxima (Table 9). Only species that can tolerate higher levels of sediment contamination, such as Nephtys incisa, Edotea triloba, Ceriantheopsis americanus, Pherusa affinis and others are found in strata groups C and D.

\section{Species associations with habitat quality}

Species classifications, based on 6 rounds of ordination for the 80 most common species, resulted in the first round of ordination defining 2 primary species groups, that appear to be either mostly 'Contaminant sensitive' (e.g. as indicated by ' 0 ' in the first column of classification code for species in Table 9) or 'Contaminant insensitive' (e.g. ' 1 ' in the first column of classification code for species in Table 9). In the second round of ordination, these 2 groups were further separated into 2 subgroups; refer to the second column of classification code for species assigned according to the presence of either a ' 0 ' or ' 1 ' in Table 9. Thus, 4 species assemblages I to IV were formed by the codes ' $00^{\prime}$, ' 01 ', ' 10 ' and ' 11 ' respectively, for each species in the first 2 columns of classification code for species (Table 9). Four additional rounds of ordination provided the refined species groupings evident in classification code for each species (Table 9).

Species group I contains species that appear to be the 'most contaminant sensitive' (as indicated by ' 00 ' in the first 2 species ordination code columns). This group's species were most common in strata group $B$, with some contribution from strata group A, e.g. Aricided wassi and Spisula solidissima (Table 9). The species common in this subgroup are rare in contaminated strata groups C and D $\left(\leq 5\right.$ per $0.1 \mathrm{~m}^{2}$; i.e. abundance Code \# being generally $\leq 3$ ).

Species group II (e.g. '01' in the first 2 species ordination codes), containing the remaining first ordination (00) group species, Exogone hebes through Amastigos caperatus (Table 9), were common in strata group $B$, but could also be found in relatively high abundance $\left(\geq 10\right.$ per $0.1 \mathrm{~m}^{2}$; abundance Code \# $\geq 4$ ) in strata groups C and D, e.g. E. hebes, Unciola irrorata, Spiophanes bombyx, Leptocheirus pinguis and Amastigos caperatus (Table 9). This suggests more contaminant tolerance than the species in group $I$.

Species group III (e.g. ' 10 ' in the first 2 species ordination codes), included species that appear to be moderately tolerant of sediment contamination (Table 9). The species in this group, although classified as contaminant tolerant in the primary ordination, may differ only in degree from the last subgroup II, i.e. subgroup III species were most common in strata groups B and C, 
with some contribution to the other groups, A and D, e.g. for group A: Nephtys picta and Tellina agilis, and for group D: species included in this habitat strata with abundance Code \# $\geq 4$ (Table 9). The 2 middle groups, II and III, including species with ' 01 ' or ' 10 ' in the first 2 species ordination code columns (Table 9), may include either moderately contaminant tolerant or sensitive species.

Species group IV (e.g. '11' in the first 2 species ordination codes), including the remaining species, Edotea triloba and below (Table 9), are also common in strata group $\mathrm{B}$ but are most common in strata groups $\mathrm{C}$ and D. A few species from the previous subgroup, i.e. Tharyx acutus, Monticellina dorsobranchialis, rhynchocoels, and Tellina agilis, appear to belong to this subgroup because of their relative abundance in strata groups $C$ and $D$, despite the ordination classification results. This last subgroup appears to include the most contaminant insensitive species, e.g. Nucula proxima, Capitella spp., Mediomastus ambiseta and Prionospio steenstrupi.

The species subgrouping revealed by the third through sixth ordination results, as indicated by the 0 or 1 coding sequences in classification code columns 3 to 6 (Table 9), could suggest closer species associations. For example, the first 9 species (codes '0000') are indicated as a group of species with the highest contaminant sensitivity. It is worth noting that Capitella spp. forms a distinct subgroup, '111101', in the ordination results, which supports the results of the correlation analysis (Table 7). For the most part these ordinationdefined primary strata groups are ecologically realistic, i.e. defining species habitat associations that are consistent with those reported in previous qualitative studies or reviews, e.g. Pratt (1973), Pearson \& Rosenberg (1978), Caracciolo \& Steimle (1983) and Steimle (1990). For example, most of the species in the contaminant sensitive group are reported to be typical of silty fine sand habitats in the Middle Atlantic Bight: Unciola sp., Euclymene zonata, Astarte sp., Ampelisca agassizi, Scalibregma inflatum and Leptocheirus pinguis (Pratt 1973). Some contaminant tolerant species are also reported to be included in this 'community' as well, e.g. Arctica islandica, Nephtys incisa, and Pherusa affinis (Pratt 1973). Nucula proxima is also found associated with these species (Steimle 1982).

Although only 80 most common species, of the 357 found in the surveys, were summarized in this analysis, another classification analysis was run with a larger number of species. This expanded analysis (not presented) contributed a few species to the contaminant insensitive group (IV), but most of the additional species were rarer and were classified into the first, most contaminant sensitive group (I) with a moderate number to the intermediate second and third classifi- cation groups (II and III). This is not unexpected as it reflects the use of a greater diversity of species found in the relatively unstressed but variable benthic habitats in the entire New York Bight. The 80-species analysis seems adequate to define important indicator species assemblages relative to habitat type and quality.

There were a few species that seemed to be misclassified by this statistical analysis, possibly because of one of the potential errors or biases mentioned previously. The strong statistical association of the tubedwelling, opportunistic polychaete, Asabellides oculata, usually found in silty sediments, with the Atlantic surf clam Spisula solidissima, and the polychaete Sthenelais limicola (Table 9), both typical of coarser, sandy sediments, is a possible spurious classification. The strong association of the blue mussel Mytilus edulis with 2 burrowing polychaetes in the same group is questionable because the mussel is typically found attached to hard substrates at or above the sediment surface. The group consisting of the burrowing, predatory rhynchocoel (undoubtedly Cerebratulus lacteus), typical of silty sediments, with the small clam Tellina agilis (Table 9), usually associated with medium to fine sands (Pratt 1973), is doubtful as well. Some of these questionable associations could also represent ephemeral recruitment to atypical habitats. Alternatively, the actual substrate upon which the species was found may not have been properly classified, e.g. Mytilus $\mathrm{sp}$. spat on a rock or shell fragment not noted in the sediment analysis data. Other inconsistencies may be due to chance, considering the large number of comparisons that were made.

The station collections within each classification analysis stratum often exhibited year to year variability in their habitat characteristics, explaining their assignment to more than 1 stratum (i.e. Table 3). For example, in 1980 Stn 4 was classified in Stratum 6 (group C), while in 1981 and 1982 the station was assigned to Stratum 3 (group B). This could suggest a number of things, including sampling error, high habitat heterogeneity at the station, or a changing environment.

\section{SUMMARY}

For the study's first purpose, both the association and correlation analyses found strong relations between sediment characteristics and putative 'indicator' species or taxa. The association analyses suggested that 3 species, Ceriantheopsis americanus, Nephtys incisa and Nucula proxima, are reasonable indicators of a fine sediment habitat with high TOC levels, and that these species were tolerant of high levels of trace metals. Capitella spp., as expected from the results of 
other studies, were indicators of high TOC and metal contamination. Crustaceans, including Ampelisca agassizi and other amphipods, as well as overall macrofaunal species density, proved to be indicators of minimally contaminated habitats. These relations were reasonably clear-cut in the analysis, but included several exceptions to these generalizations.

The classification analysis, using a broader range of benthic species (the 80 most abundant) with no further pre-selection, addresses the second purpose of this study and suggests that there are commonly co-occurring species in relatively high abundances which are reliably associated with specific habitat types, defined by sediment characteristics and quality. There appear to be 2 primary species groups, one consisting of sediment contamination-sensitive species and the other containing basically tolerant species, but there is overlap among the groups, with some species occurring in both. Strata group B appears to contain species that are representative of the basic benthic habitat community in the New York Bight. This group includes all contaminant insensitive species and many tolerant ones, as well. Strata groups C and D contain more contaminant tolerant species that are common in the upper Hudson Shelf Valley and areas adjacent to waste disposal sites. Strata-group A appears to be a unique exception and could represent either sampling or analytical error or special habitat conditions.

Our analyses generally support the use of certain species or taxa for indicating habitat quality. They also suggest other potentially useful species or speciesgroups that are strongly associated with certain habitat types and levels of quality. A major assemblage of species was defined that appears to represent a basic, dominant, natural benthic community in the New York Bight. The associations and definitions suggested by the statistical approaches used here were mostly ecologically realistic, based on comparison with other studies, but there were occasional exceptions.

Acknowledgements. We thank Joseph Vitaliano and Ann Frame for their assistance with taxonomic nomenclature, and Michael Fahay, Anne Studholme and Stuart Wilk of Sandy Hook Laboratory, Robert Murchelano and John B. Pearce of Woods Hole Laboratory, and anonymous reviewers for their critical comments and valuable suggestions.

\section{LITERATURE CITED}

Bartlett, M. S. (1947). Multivariate analysis. J. R. statist. Soc. Ser. B: $176-197$

Box, G. E. P., Cox, D. R. (1964). An analysis of transformations. J. R. statist. Soc. Ser. B: 211-252

Caracciolo, J., Steimle, F. W. (1983). An atlas of the distribution and abundance of dominant benthic invertebrates in the New York Bight apex, with reviews of their life histories. NOAA Tech. Rept. NMFS SSRF-776
Cooley, W. W., Lohnes, P. R. (1971). Multivariate data analysis. John Wiley and Sons, New York

Eagle, R. A., Rees, E. I. S. (1973). Indicator species - a case for caution. Mar. Pollut. Bull. 4(2): 25

Gauch, H. G. (1982). Multivariate analysis in community ecology. Cambridge Univ. Press, Cambridge

Grassle, J. P., Grassle, J. F. (1976). Sibling species in the marine pollution indicator Capitella (Polychaeta). Science 192: $567-569$

Green, R H., Vascotto, G. L. (1978). A method for the analysis of environmental factors controlling patterns of species composition in aquatic communities. Mar. Res. 12: 583-593

Halcrow, W., Mackay, D. W., Thomson, I. (1973). The distribution of trace metals and fauna in the Firth of Clyde in relation to the disposal of sewage sludge. J. mar. biol. Ass. U.K. 53: 721-739

Hill, M. O. (1973). Reciprocal averaging: an eigenvector method of ordination. J. Ecol. 61: 237-249

Hill, M. O. (1979). TWINSPAN - A Fortran program for arranging multivariate data in an ordered two-way table by classification of the individuals and attributes. Section of Ecology and Systematics. Cornell Univ., Ithaca

Hill, M. O., Bunce, R. G. H., Shaw, M. W. (1975). Indicator species analysis, a divisive polythetic method of classification, and its application to a survey of native pinewoods in Scotland. J. Ecol. 63: 597-613

Johnson, R. G. (1971). Animal-sediment relationships in shallow water benthic communities. Mar. Geol. 11. $93-104$

Lee, W. Y., Welch, M. F., Nicol, J. A. (1977). Survival of two species of amphipods in aqueous extracts of petroleum oils. Mar. Pollut. Bull. 8: 92-94

Long, E. R., Morgan, L. G. (1990). The potential for biological effects of sediment-seabed contaminants tested in the National Status and Trends Program. NOAA Tech. Memo. NOSOMS-52

Pearce, J. B., Thomas, J , Caracciolo, J., Halsey, M., Rogers, L. (1976). Distribution and abundance of benthic organisms in the New York Bight apex, 2-6 August 1973. NOAA TR ERL MESA-8

Pearson, T. H., Rosenberg, R. (1978). Macrobenthic succession in relation to organic enrichment and pollution of the marine environment. Oceanogr mar. Biol. Ann. Rev. 16: $229-311$

Pratt, S. (1973). Benthic fauna. In: Coastal and offshore environmental inventory, Cape Hatteras to Nantucket Shoals, Chap. 5. Univ. Rhode Island, Kingston

Puri, M. L., Sen, P. K. (1971). Nonparametric methods in multivariate analysis. Wiley and Sons Publ. Co., New York

Reid, R. N., O'Reilly, J. E., Zdanowicz, V. S. (eds.) (1982). Contaminants in New York Bight and Long Island Sound sediments and demersal species, and contaminant effects on benthos, summer 1980. NOAA Tech. Mem. NMFS$\mathrm{F} / \mathrm{NEC}-16$

Reid, R. N., Radosh, D. J., Frame, A. B., Fromm, S A. (1991). Benthic macrofauna of the New York Bight, 1979-89. NOAA Tech. Report NMFS 103

Rhoads, D. C. (1974). Organic-sediment relations on the muddy sea floor. Oceanogr. mar. Biol. Ann. Rev. 12: $263-300$

Rowe, G. T (1971). The effects of pollution on the dynamics of the benthos of the New York Bight. Thalassia jugosl. 7(1): $353-359$

Saila, S. B., Pikanowski, R. A., Vaughan, D. S. (1976). Optimum allocation strategies for sampling benthos in the New York Bight. Estuar. coast. mar. Sci. 4: 119-128 
Sanders, H. L., Grassle, J. F., Hampson, G., Morse, L. GarnerPrice, S., Jones, C. (1980). Anatomy of an oil spill: longterm effects from grounding of the Florida off West Falmouth, MA. J. mar. Res. 38: 265-380

Siegel, S. (1956). Nonparametric statistics for the behavioral science. McGraw-Hill Book Co., New York

Steele, R., Torrie, T (1960). Principles and procedures of statistics. McGraw-Hill Book Co., New York

Steimle, F. W. (1982). The benthic macroinvertebrates of the Block Island Sound. Estuar. coast. shelf Sci. 15: 1-16

Steimle, F. W. (1985). Biomass and estimated productivity of the benthic macrofauna in the New York Bight: a stressed coastal area. Estuar. coast. Shelf Sci. 21: 539-554

Steimle, F. W. (1990). Benthic macrofauna and habitat monitoring on the continental shelf of the northeastern United States I. Biomass. NOAA Tech. Report NMFS 86

This article was presented by $K$. Sherman, Narragansett, Rhode Island, USA.
Steimle, F. W., Caracciolo J., Pearce, J. B. (1982). Impacts of dumping on New York Bight apex benthos. In: Mayer, G. (ed.) Ecological stress and the New York Bight: science and management. Estuarine Research Federation, Columbia, SC, p. 213-224

Stubblefield, W. L., Dicken, M., Swift, D. L. (1974). Reconnaissance of bottom sediments on the inner and central New Jersey shelf (MESA Report No. 1). Superintendent of Documents, U.S. Government Printing Office, Washington, D.C.

Walker, H. A., Saila, S. B., Anderson, E. L. (1979). Exploring data structure of New York Bight benthic data using postcollection stratification of samples, and linear discriminant analysis for species composition comparisons. Estuar. coast. mar. Sci. 9: 101-120

Manuscript first received: May 4, 1992

Revised version accepted: September 28, 1992 